\title{
TRADITIONAL GAMES AND FUN OF THE ROMA COMMUNITY INHABITING EASTERN POLAND. AN ANTHROPOLOGICAL- ETHNOMETHODOLOGICAL PERSPECTIVE
}

\author{
ERNEST SZUM, RYSZARD CIEŚLIŃSKI \\ The Josef Pilsudski University of Physical Education in Warsaw, \\ Faculty of Physical Education and Sport in Biała Podlaska, Department of Pedagogics
}

\author{
Mailing address: Ryszard Cieśliński, Faculty of Physical Education and Sport, Department of Pedagogics, \\ 2 Akademicka Street, 21-500 Biała Podlaska, tel.: +48 83 3428776, fax: +48 83 3428800, \\ e-mail: knh@awf-bp.edu.pl
}

\begin{abstract}
Introduction. The Roma for strangers are a people of serenity and fun. By the majority of the Polish society they are perceived as people who have lost touch with a broader context of social reality. The aim of the research was to gather material concerning traditional Gypsy fun and games, systematize the knowledge about the physical culture of the Polish Roma and also determine the sense of social actions taken within the scope of games and fun of this ethnic group. Material and methods. The research, belonging to the current of anthropological-ethnological thought, was carried out among the Roma from the eastern part of Poland. The findings were presented as elements of non-material culture and a form of physical activity of this ethnic group. The traditional games and fun of the Polish Roma were presented against the background of general characteristics of the ethnic group and the entire history of the Gypsies presence on Polish soil. Results and conclusions. The research has shown that the physical culture of the Polish Roma, displayed in the form of games and fun, is crucial for strengthening the existing social bonds and shaping new ones. The research has proven that the joint physical culture of the Polish Roma, being an integrating factor, initiates and intensifies social interactions, and is conducive to the development of interpersonal relations. It has been found that there are patterns of physical culture and forms of physical activity of characteristic of the Roma community. The study and the interpretation of the findings, has enabled the authors to systematize the knowledge on the physical culture of the Polish Roma, and also determine the sense of the actions taken by them in this scope.
\end{abstract}

Key words: Gypsies, the Roma, physical culture, the games and fun, free-time sociology, ethnology, cultural anthropology

\section{Introduction}

When deliberating on the Roma community in Poland and the issues related to it, the elementary question is the genesis of the terminology - Gypsies and the Roma. Despite some negative connotations that are borne by the term Gypsies, it must be applied referring to the history of the contemporary Roma. Therefore, it is often used interchangeably with the term "Roma". Although, there are a number of arguments in favour of to use the term "Roma". Its introduction and the fact that they identify with this name, are desired nation-forming and culture-forming phenomena [1].

Officially, the term "Roma" has functioned in the Polish language since 1979, when the Polish Episcopate founded the National Roma Chaplaincy [2]. An argument in favour of using this term is also its easy assimilability and lack of negative associations with the past. Whereas the term "Gypsy" derives from the new-Greek word athiganoi, meaning "the untouchable" [3]. In the historical context it seems more legitimate to use the term "Gypsy" when speaking about the contemporary Roma population.

The roots of the Roma people are in India. However, according to a number of scientific theories, Gypsies as a social group with their own personality and cultural identity, appeared only when after long migration they found themselves on the border of Asia and Europe. Their presence in Europe formed their identity and the acquisition of their name. In the $15^{\text {th }} \mathrm{c}$. they moved to other parts of the continent. Also then they reached Polish soil. They merged with social and religious reality present in the entire Europe. In the majority of European countries they were made welcome and were granted special privileges by some rulers $[4,5]$.

In the $16^{\text {th }}$ c. together with the consolidation of the Renaissance philosophy treating work as a duty, a watershed took place in the situation of Gypsies. From then on people perceived them as vagabonds and slackers. It resulted in persecution and introduction of laws that were unfavourable and oppressive for the Gypsies. It happened also in Poland, where the first anti-Gypsy law was issued in 1557 [6].

After WWII the governments of both the Eastern Block and the democratic countries aimed at transforming Gypsies into a settled community who lead a lifestyle similar to the majority of indigenous European societies.

In the post-war Poland four watershed events may be singled out. The first one is the issuance of a resolution in 1952, aimed at permanent settlement and employment of the Gypsy community. The actions taken enabled the state institutions to supervise the Gypsy community [7, 8].

Another anti-Gypsy move by the Polish authorities was the immobilization of the Gypsy trains of wagons, which were part of the old Gypsy tradition. The forced settlement was carried out by virtue of the over-interpretation of various legal acts e.g. on fire safety, on fighting contagious diseases, or on assemblies. However, the Gypsies were entirely settled as late as the end of 
the 1970s [8].

Another watershed took place at the beginning of the 1990s. It was related to the contemporary public feeling and the events that ensued from them. The hostility towards the Roma also increased then. In the autumn of 1981 two serious Polish-Gypsy incidents took place, in Konin and Oświęcim. In both cases, minor conflicts between Poles and the Roma triggered a disproportionate Polish reaction and caused the persecution of the Roma [8].

The most striking results were produced by the fourth watershed i.e. the pogrom of the Roma in Mława. The event took place in June, 1991. The Roma realized then how helpless they were in a threat situation, and that they needed to create an organization representing their business and able to protect their civic rights. The Mława pogrom played an important role in the process of shaping the ethnic identity of the Roma and their group consolidation and social-political mobilization $[8,9]$.

Today, on the Polish and also European scale, the Roma, as an ethnic group and national minority occupy a specific position $[1,10]$. They are an ethnic group living in a diaspora. They do not have their own territory and do not aspire to it. In the second half of the $20^{\text {th }} \mathrm{c}$. they started to shape their ethnic identity and to demand the political rights of a national minority, although in the opinion of some scientists they do not form a nation [5, 7, 11]. The Roma, in all the societies they are part of, constitute a minority, and their legal and social situation, as a social group, is always dependent on the state in which they exist, and on the position of the dominant majority [11,12].

In Europe and the world occur a number of Gypsy communities. Neither in Poland did the Gypsies constitute a homogenous community. They are divided into groups, often hostile to each other. It results both from the difficulties in communication, because particular groups speak different dialects, and the different form of intra-group authority, and also from other culture-related differences. However, the Gypsy elites try to diminish the significance of the factors, so the homogenous Roma community in Poland will be created [3, 4, 7] (Fig. 1).

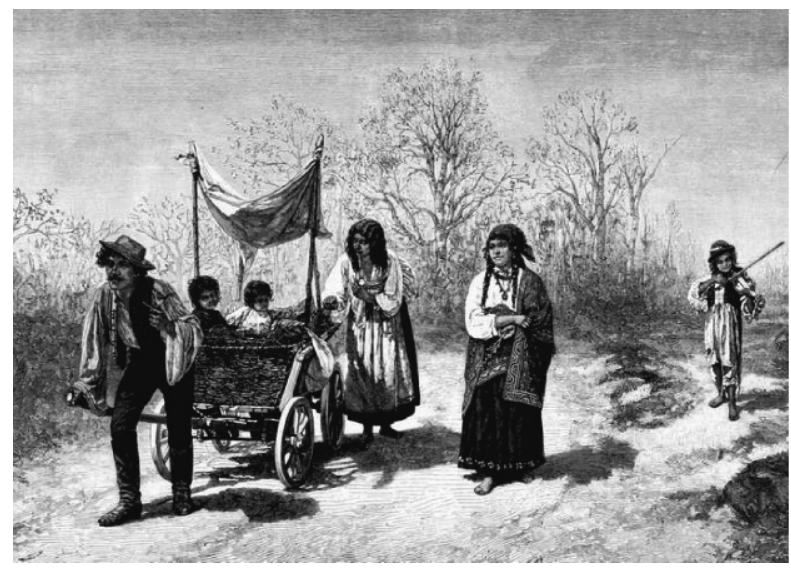

Figure 1. Gypsy family $-19^{\text {th }}$ C. [22]

The simplest sort division of the Polish Roma, is to single out groups, taking into account their language dialects, lifestyles and customs. On the basis of such categorization one may point at four basic groups, referred to as tribes (ethnic factions).

The most numerous group is the so called Polska Roma. It includes Polish lowland Gypsies, present on the Polish soil since the $16^{\text {th }} \mathrm{c}$. Within the group one may single out a number of subgroups e.g. Haladytka Roma, Sasytka Roma, Varmiyaki, Yaglaki, Vengry, Bosaki, Berniki, Tonyaki, Servy, Plunaki, Pahoviaki, Kaliszaki and others. The division into subgroups is related to the names of families and the time they came to Polish land, and also with later relations within the group. The Gypsies from the Polska Roma are an indigenous group in Polish territory. In everyday life they are driven by strong custom rules, which are watched over by Baro Siero (the Big Head) or Siero Rom (the Gypsy Head) [3, 6, 13].

The second basic group are Kelderashe (pot makers). They appeared on Polish soil in the $19^{\text {th }}$ c. migrating from Romania. Initially they earned their living as pot makers, hence their name. Kelderashe form the Gypsy elite, both in Poland and worldwide. Inside the group they are not so consolidated and loyal. Kelderashe swallowed up minor groups that came to Poland together with them, with one exception [3, 6, 8].

The exception are the third group - Lovary. Culturally they are closest to Kelderashe. Lovary migrated to Poland in the same period but from Hungary. They dealt in horses, and today they buy and sell cars. They consider themselves the Gypsy aristocracy, and they gladly demonstrate it, living in luxury. Like Keldereashe, Lovary are present in many societies all over the world [3,6].

The fourth basic group is formed by the highland Gypsies Bergitka Roma. They are treated condescendingly by other Gypsies, because they seclude themselves from the other groups. For several generations they have led a settled lifestyle, mainly in the south of Poland. In the past they dealt with fortunetelling, but they changed this occupation into a simpler one begging. Before they earned their living as craftsmen, now they gladly take up physical work. Bergitka Roma are the poorest Gypsy group in Poland. Its members are the lowest in the Gypsy social stratification $[3,6]$.

\section{Material and methods}

The aim of the research, conducted on the Polish Roma community, was to gather material concerning traditional games and fun that function within this ethnic group and systematize knowledge on their physical culture. Besides, the generalized aim was to determine the sense of social actions taken within the scope of the Roma games and fun.

The research comprised thirty people (both women and men) who represent the community of the Polish Roma living in eastern Poland, first of all towns and villages of the Podlasie region and the northern Lublin region, which are referred to as Southern Podlasie. The Roma living in eastern Poland are not very much different, when compared to the representatives of the ethnic group from other regions of the country, and their social activity (including physical culture, and more precisely games) does not have any special features resulting from the place of residence.

The researched group was chosen at random. It was conditioned by the contact of the researchers with anonymous respondents during accidental encounters in the street, at marketplaces, near train stations and supermarkets. The Roma reluctantly talked in their homes and even refused to have such contacts.

The research was conducted during the years 2012-2013 among males (22 persons) and females ( 8 persons) Roma, living in the following locations of eastern Poland: Białystok, Bielsk Podlaski, Siemiatycze, Biała Podlaska, and Międzyrzec Podlaski. It must be underlined that the women more willingly answered the questions when there were male Roma around (such a situation took place in two interviews). More profound knowledge was displayed by the men.

When conducting the study, which is in the ethno-methodological current, the authors used a qualitative method of a survey, free interview and observation. The applied method is part of quality studies, based on empirical material. It involves a number of theoretical and methodological assumptions, con- 
cerning the research process, from the introductory stage to the analysis of the findings $[14,15]$.

The choice of the qualitative method of conducting the research was dictated by the need to deepen the knowledge about the physical culture of the Polish Roma, and more precisely on the exemplifications of the traditional games of this ethnic group. The traditional Gypsy game, as a little fragment of the social life of the modern Polish Roma, can be studied using the qualitative, applying the interview technique [16]. The description and structural-functional analysis of the research issues, were complemented with recordings and historical elaborations, which introduce the subject of the Roma.

The methodological framework of the research was determined by the paradigm of modern cultural anthropology - the relationship between the culture and the entirety of the social life of the studied group. Nevertheless, as the main aim of the research, the authors chose the priority of ethnological sciences, i.e. presenting the cultural specifics of the studied community, as well as its place and role in a broader social environment [17]. In the case of the presented research, the research subject was to determine the mutual relations, influences and to point at potential dependences between the Roma ethnic group and the Polish society.

\section{Results}

From the accounts gathered during the interviews, which are the basis of the analyzed findings, it ensues that among numerous Roma games, one can encounter both team and individual games. Among them there are sports for adults and children. the games and fun can be divide depending on the sex, because there are games specific for men and women, or they are attributed roles in the games. However, many Roma games have no age or sex limitations.

For centuries the Roma competed and challenged each other in sports involving throwing objects of all kind. Most often it was knife-throwing. The competitors threw them at a target a round board, or around a target - a human being. Usually the men threw the knives around a woman who was standing at some distance, at a tree or a specially-prepared wooden board. Equally often Gypsies threw an axe or a hatchet, or several such objects. It was organized in the same form as knife-throwing. A little different was horseshoe-throwing. Most often the competitors threw at the lower part of a small stump, or a wooden stake or a metal rod dug in. The purpose was to throw the horseshoe so that it is around the stump. A curiosity in throwing games was a "culinary-sport" game i.e. throwing a piece of ham at a frying pan. The competitors threw a thick slice of ham at the pan which was being held by another person. The smaller was the range of movement of the person who was holding the pan, the better evaluation was received by the thrower. In poorer families or Gypsy groups, during the competition, ham was replaced by cheaper meat e.g. bacon.

Among games and fun that have their origin in the Gypsy tradition, the greatest interest and emotions of the Polish Roma was aroused by team games, which on the one hand integrated the group and on the other hand required competition with strangers. They were: wheel-rolling, tug-of-war, "kręciołek" ("spinner"), egg-filching or "narty Bolka” (Bolek's skis).

The wheel-rolling consisted in pushing forward a large wooden cart wheel or (later) bicycle wheel or car tyre. The game was played both by adults, youth and children. It assumed the form of an individual or team game. In the first case one person was racing another one while rolling a wheel. Whereas, in the second version, several people together or interchangeably rolled the wheel, competing with the rivals. The winner was the one who had rolled the wheel to the spot chosen before. The wheel-rolling in other versions consisted in the competition in the distance covered or the precision of rolling. The game is still popular with the Roma children. However, today they use the tyres as improvised swings.

Tug-of-war was a very simple game. In the game two groups of people, set at the two ends of the rope, pulled it in two opposite directions. Very often the rope was situated over a ditch which was in the middle of its length. It happened that one team pulled the other one into the water, which made the game more attractive. The winners were those who pulled the rope to a special point or pulled the rope so hard that the other team let go of the rope or fell down. The sport was most popular in Gypsy community at the beginning of the $20^{\text {th }} \mathrm{c}$. The Roma often competed in tug-of-war with their own teams or strange ones. The competition with strangers allowed them to prove their superiority not only in terms physical strength, but also in the scope of team play, which was particularly appreciated. However, in that period i.e. the turn of the $19^{\text {th }}$ and $20^{\text {th }}$ C., tug-of-war was popular worldwide, and in the first decades of the $20^{\text {th }}$ c. it was an Olympic event.

"Kręciołek" ("spinner") has always been the children's game. It consisted in spinning on one's axis, not changing one's position or moving a bit. The spinning person reaches out their arms, which helped keep a balance. The Gypsy children played at this game individually or in small groups. The winner was the person who spun longest, and after he finished spinning, he had to stand on their feet. When all the competitors fell down on the floor, the winner was the one who fell last. The game is still popular with the Roma children, and its formula and rules have remained the same.

Egg-filching is Gypsy children's game currently lesserknown among the Roma community. Although a relatively high number of people have heard of it, not many of them are able to explain the rules of the game. The egg-filching rules were based on the competition between a person and a group. The children chose one person from the group. The person's task was to keep eggs in a basket. Instead of eggs, the children used apples or even potatoes (rarely), but the game bore the name "egg-filching”. In the period when the Gypsy led a nomad lifestyle, the children filched eggs, apples, potatoes from the nearby farms. The remaining people dispersed in order to find concealment. The person guarding the eggs had to find all the children, not losing the eggs from the basket. The remaining players tried to filch the eggs from the basket, when the guardian walked away from the basket. The winner was the person who filched the highest number of eggs, when the basket had already been empty. The guardian could also win if he found all the children before they filched all the eggs. The game is similar to a game popular in Poland, i.e. hide-and-seek, in the variant, where instead of eggs, a ball was used. The ball was struck from the "base", while he was away in search of the players who were hiding.

The essence, origin and rules of the game called "narty Bolka" ("Bolek's skis") have not been found. In the Roma's joint memory all that survive was its name. It is an example of a fragment of Gypsy culture, in this case of physical culture, the knowledge of which has not survived. The cause is lack of written sources. We even do not know whether it was an individual or team game, and whether it involved elements of competition.

The Roma have always enjoyed competitions and games involving animals. First of all their beloved animals were horses. They often emphasize: "we have always loved horses". They enthusiastically practised horse-riding, both horse racing and stunt riding. Games of this kind often included elements of horse acrobatics and cowboy horse-riding. Nevertheless, horseracing competitions were seldom held, probably due to the anxiety over the injuries that the horses could receive. Gypsies on a 
large scale dealt in horses.

Before, Gypsies specialized in taming and training bears, which were a popular attraction when the Roma visited a location. The shows with trained bears was a common Gypsy activity when forests were full of these animals, especially in eastern Poland. The Gypsies taught young bears how to do a dance, perform equilibristic sets, acrobatic jumps, gymnastics, and a number of tricks. During a show in front of the audience, the bear trainer, very often participated in the presented games as partners of the animals. The modern Roma remind with pride that in the mid- $18^{\text {th }}$ c. the Smorgon Bear Academy was famous in the entire Europe. The academy was run by the Gypsies settled in the estate of the Radziwiłł family (Fig. 2).

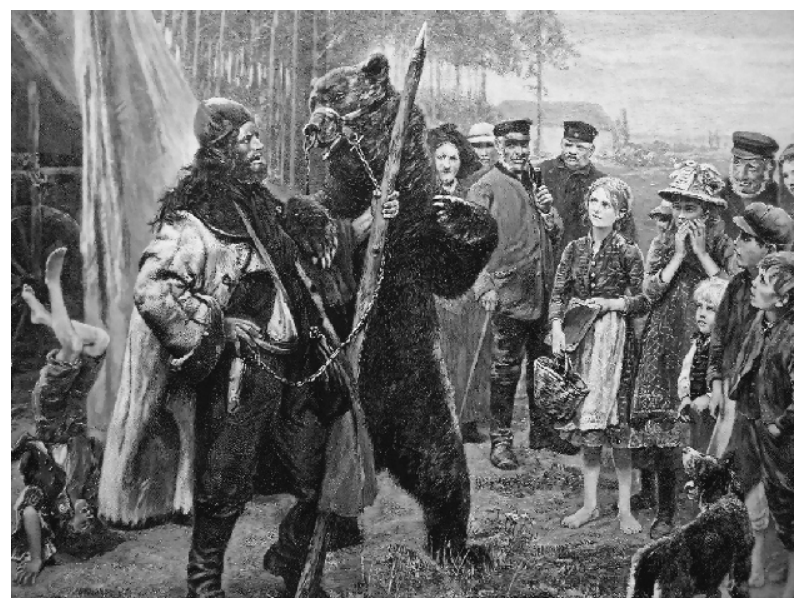

Figure 2. The bear trainer show $-19^{\text {th }}$ C. [22]

In the past the Gypsies also did the sport of goat-milking. It was an event that required agility, settled with time criteria. The winner was the one who first finished the activity. Besides other popular games among the Gypsies were: the election of the Gypsy King, tambourine contest, dances with knives in the mouth, collecting prizes and many others which were their variants and differed only with the use of other accessories.

Another form of fun and, at the same time, a specific interpersonal game, is the traditional Gypsy dance. The individual female and male dance differ considerably from each other. In the traditional dance the Gypsy women take quick strides, maintaining straight silhouette. The trunk is parallel with the legs, does not bend forwards or backwards. The head - almost still - is a bit raised, which adds dignity to the dance. During the dance the arms, forearms and hands are in dynamic motion. The arms wave along the body, rising above the shoulders and the head, then slowly and smoothly go down, interchangeably folding and unfolding hands. The movements are often accompanied by hand-clapping. In the traditional Gypsy dance the details and the subtlety of the movements of the fingers are very important. In the movements niceties of all kinds are expressed, understood clearly by the audience at the sensual, intellectual and emotional level. Whereas in the male dance there is more dynamics, impulsiveness which sometimes assumes the form of impetuosity. Their dance has a faster tempo, is less schematic, less smooth and less organized, and has frequent turns. The dancer beats out the cadence stamping his feet and clapping his hands against his chest, thighs and shins. The Gypsy audience gathered around the dancers, shout, whistle, and also rhythmically clap their hands or bang their hands on pots, supporting the performers and even replacing them.

In the games and fun of the adult Roma also the children take part. They participate in the social life of the community from early childhood. The interactions with the adults allow them to naturally enter the adult world. Thanks to joint participation in the games and fun they can learn how to correctly perform social roles.

The culture and tradition of the Roma, within the scope of physical culture, displayed in the form of games and fun, are best depicted by the social events such as: the Gypsy carnival and celebrations related to religion. The time of carnival and ritual religious celebrations, ideally introduce broader social-cultural functions and the sense of the Roma games and fun. The Gypsy carnival is a festival of traditional customs, ludic behaviour, and also the expression of functioning of social mechanisms, resulting from the values and cultural patterns of the Roma ethnic group. They usually have a hermetic dimension, reserved only for the members of their own group.

\section{Discussion}

The term "social group" created by Znaniecki, in order to determine an ethnic group, defines "social group" as any association of people that in their consciousness consists a whole. The consciousness factor determines in this case the sense of identity, which is one of the most important element of ethnic identity. A group exists only when its members consider it as existing and different from the rest of the social world, which, of course, does not mean losing contact of the individuals with the world [18]. Nevertheless, the term "ethnic group", according to the definition by Weber, refers to communities connected with the faith in the joint origin, which have not attained the status of civic-political societies and do not have their own state. The indicators of ethnicity are: endogamy, caste system, family system of social organization [19]. Kubiak defined "ethic group" as a specific product of the migration-settlement process. Therefore, it is a community - within a broader society - accepting only their own cultural patterns. Their specific business are formed under the influence of the cultural heritage of the country of origin, as a result of the contact with the reality of the country of settlement [20]. The above-mentioned definitions of "ethnic group" may successfully be applied to the general characteristics of the Polish Roma.

The Gypsy wagons trains have not crossed Polish territory for many years. Today, one cannot learn the traditional aspects of the Roma life and culture, as well as their customs, through the contact the Gypsies, who used to visit the cities, towns and villages of Poland. In the times when the wagons trains sooner or later reached the majority of human settlements, the Polish society could get acquainted with the Gypsies' everyday life and their culture, including the games they played and the fun they had in their free time. The games and fun were an important element of the celebration [21].

Gypsy culture is commonly known, first of all from musical forms, songs, dances and also expressed in the form of stories, legends, fairy tales and adages. What is interesting is the fact that the Roma folklore is totally devoid of plastic arts. Due to lack of the written form, many products of immaterial Roma culture have been deformed and a part of them have been forgotten [3, 4]. It also concerns the games and fun. Some of them are still practised by the Roma, and others have been abandoned, yet the knowledge about them has remained. However, there games which have irretrievably been lost.

Despite the existence of many valuable elaborations on the history of Gypsies on Polish soil, it must be underlined that they only marginally talk about the issues associated with physical culture. Nevertheless, the aspects connected directly with games and fun, are simply omitted. None of the elaborations on the broadly understood physical culture, do not present to a sufficient degree, the physical culture of this ethnic group. The is- 
sues more or less related to the subject appeared in the papers of the researchers of the Gypsy Roma culture, but have never been the main research area in this scope $[3,4,6]$. There are still not enough elaborations presenting the subject of the physical culture of the Polish Roma from the ethnological and anthropological perspective. Therefore, the above-presented research concerning traditional Gypsy games and fun, as forms of physical culture of the modern Roma, should be treated as pioneer for the ethnic group.

\section{Conclusions}

The above-presented research allowed the authors to gather material concerning traditional Gypsy games and fun, systematize the knowledge about the physical culture of the Polish Roma, and determine the sense of social actions taken within the scope of the games of this ethnic group.

An analysis of the material gathered during the research on the Roma community inhabiting eastern Poland, has shown that their physical activity manifested in the form of games and funis vital for the strengthening of social bonds and shaping new ones. The games, being an expression of the organization of the social life, provide the Roma with the conditions to shape their ethnic identity strengthen the sense of community. Nevertheless, the element of competition that can be found in the games and fun, releases solidarity-building behaviour. Moreover, the joint physical activity, being an integrating factor, initiates and intensifies social interactions, and is conducive to the development of interpersonal relations. The physical culture of the Roma community, especially its traditional elements, are an extremely important part of forming and consolidating the national identity of the Polish Roma.

The physical culture of the Polish Roma, including their games and fun, is changing nowadays, like the broadly understood culture of this ethnic group. The evolution of the forms of their physical culture is comparable to the changes taking part in the physical culture of other national minorities living in Poland, with equally rich traditions.

The changes occurring in the Roma community feature the disappearance of certain elements of the culture of the group, and the acquisition of elements of the culture of the Polish majority. The process to some degree is caused by the influence of the global trends. Despite the occurrence of the changes, many features that underline the Roma identity are still sustained, which is possible thanks to the existence and functioning of he social control within the group. It functions, first of all, in the form of the phenomenon called "sullying", i.e. the "impure" activities of all kind. The full range of the behaviour permitted and present in the Roma custom, is determined by the mageripen code $[6,13]$.

As a result of the conducted research it has been found that there are some patterns of physical culture and forms of physical activity characteristic of the Roma community. The physical culture of this ethnic group is characterized by the physical activity containing elements that do not occur in the culture of other national communities or ethnic groups. It refers to the strictly sports and recreational aspect of the subject, and the everyday activities that require physical effort - work and leisure , and also festive rituals - social and religious. The research and the interpretation of its findings, enabled the authors to gather information on traditional Gypsy games and systematize the knowledge about the physical culture of the Polish Roma, and also to determine the sense of the social actions taken in the scope.

\section{Literature}

1. Kubiak H. (1980). Ethnic assimilation on the plane of social structure. In H. Kubiak, A.K. Paluch (Eds.), Assumptions of theory of assimilation (pp. 53-66). Wrocław-Warszawa-Kraków-Gdańsk: Zakład Narodowy im. Ossolińskich. [in Polish]

2. Bartosz A. (2004). Do not be afraid of a Gypsy. Na dara Romestar. Sejny: Fundacja Pogranicze. [in Polish]

3. Ficowski J. (2000). Gypsies in Poland. History and customs. Gdańsk: Tower Press. [in Polish]

4. Fraser A. (2001). History of Gypsies. Warszawa: Państwowy Instytut Wydawniczy. [in Polish]

5. Mirga A., Mróz L. (1994). Gypsies, otherness and intolerance. Warszawa: Wydawnictwo Naukowe PWN. [in Polish]

6. Ficowski J. (1985). Gypsies on Polish roads. Kraków: Wydawnictwo Literackie. [in Polish]

7. Mirga A. (1998). The Roma - the process of shaping the political subjectivity. In P. Madajczyk (Ed.), National minorities in Poland. The Polish state and society, and national minorities in the periods of political watersheds (1944-1989) (pp. 110-179). Warszawa: Instytut Studiów Politycznych PAN. [in Polish]

8. Mirga A. (1997). The Roma in the newest history of Poland. In Z. Kurcz (Ed.), National minorities in Poland (pp. 153179). Wrocław: Wydawnictwo Uniwersytetu Wrocławskiego. [in Polish]

9. Giza-Poleszczuk A., Poleszczuk J. (2001). Gypsies and Poles in Mława - an ethnic or social conflict? In A. Jasińska-Kania (Ed.), Difficult neighbourhood, from the sociology of ethnic conflicts (pp. 221-247). Warszawa: Wydawnictwo Scholar. [in Polish]

10. Jałowiecki B. (1992). Regional question. Sociological Studies 1-2, 43-62. [in Polish]

11. Kwadrans Ł. (2002). Nation - nationality - ethnic group? An attempt at creating a sociological portrait of the Polish Roma. MA thesis, Uniwersytet Opolski, Opole. [in Polish]

12. Żołędziowski C. (1995). National minorities in Poland. In M. Księżopolski (Ed.), Poland 1995. The Report on social development (pp. 18-29). Warszawa: Program Narodów Zjednoczonych ds. Rozwoju. [in Polish]

13. Kowarska A.J. (2005). The Polish Roma. Tradition and modernity. Warszawa: DiG. [in Polish]

14. Cieśliński R. (2010). Selected methods and techniques of field research in the field of sport and recreation ethnology. In I. Cieśliński, R. Cieśliński, I. Chaliburda (Eds.), Traditional forms of physical activity of the population of the eastern borderland of Poland (pp. 53-69). Biała Podlaska: AWF. [in Polish]

15. Babbie E. (2004). Social research in practice. Warszawa: Wydawnictwo Naukowe PWN. [in Polish]

16. Giddens A. (2010). Sociology. Warszawa: Wydawnictwo Naukowe PWN. [in Polish]

17. Burszta W.J. (1998). Anthropology of culture. Themes, theories and interpretations. Poznań: Zysk i s-ka. [in Polish]

18. Znaniecki F. (1988). An introduction to sociology. Warszawa: Wydawnictwo Naukowe PWN. [in Polish]

19. Weber M. (1994). The nation. In J. Hutchinson, A. Smith (Eds.), Nationalism (pp. 21-25). Oxford: Oxford University Press.

20. Kubiak H. (1980). Theory, ideology, the policy of assimilation. A sketch of the problem. In H. Kubiak, A.K. Paluch (Eds.), Assumptions of theory of assimilation (p. 17). Wrocław-Warszawa-Kraków-Gdańsk: Zakład Narodowy im. Ossolińskich. [in Polish] 
21. Huizinga J. (2007). Homo Ludens. Fun as a source of culture. Warszawa: Czytelnik. [in Polish]

22. Grajewski L. (1972). Bibliography of illustrations in Polish journals in $19^{\text {th }}$ and beginning of $20^{\text {th }} \mathrm{C}$. Warszawa.

Submitted: September 30, 2013

Accepted: December 3, 2013 